\title{
Title:
}

\section{Small bowel angioedema. An unusual condition with interesting differential diagnosis}

\section{Authors:}

Francisco J. González Sánchez, Maréa José Galante, Carmen González-Carreró Sixto, Javier García Poza, Sara Sánchez Bernal, Beatriz Castro Senosain, Inés García

DOI: $10.17235 /$ reed.2021.8407/2021

Link: PubMed (Epub ahead of print)

Please cite this article as:

González Sánchez Francisco J., Galante Maréa José, González-Carreró Sixto Carmen, García Poza Javier, Sánchez Bernal Sara, Castro Senosain Beatriz, García Inés. Small bowel angioedema. An unusual condition with interesting differential diagnosis. Rev Esp Enferm Dig 2021. doi: 10.17235/reed.2021.8407/2021.

This is a PDF file of an unedited manuscript that has been accepted for publication. As a service to our customers we are providing this early version of the manuscript. The manuscript will undergo copyediting, typesetting, and review of the resulting proof before it is published in its final form. Please note that during the production process errors may be discovered which could affect the content, and all legal disclaimers that apply to the journal pertain. 
Small bowel angioedema. An unusual condition with interesting differential diagnosis

Francisco J González Sánchez ${ }^{1}$, María José Galante ${ }^{1}$, Carmen González-Carreró Sixto ${ }^{1}$, Javier García Poza ${ }^{1}$, Sara Sánchez Bernal ${ }^{1}$, Beatriz Castro Senosain ${ }^{2}$, Inés García ${ }^{2}$

${ }^{1}$ Radiology Department and ${ }^{2}$ Gastroenterology Department. Hospital Universitario Marqués de Valdecilla. Santander

Keywords: Hereditary angioedema. Small bowel. Ultrasound. CT scan.

\section{Corresponding Author}

Francisco J González Sánchez

Radiology Department. Hospital Universitario Marqués de Valdecilla. Santander b942@humv.es

Avda Santander s/n 39003. Santander. Spain

Dear Mr Editor,

We present the case of a 35-year-old woman with a prior history of hereditary angioedema (HA) who was admitted to the emergency department with epigastric pain, vomiting and sweating. 
Laboratory tests showed raised APR levels (CRP and leukocytosis).

An ultrasound examination was performed (Fig. 1) showing significant bowel wall thickening with obvious submucosal edema, without hyperemia. Extensive ascites was also documented.

CT scan ruled out intestinal obstruction and confirmed the presence of distended proximal and mid ileum loops with severe wall thickening and submucosal edema that showed significant subserosal enhancing. Also mesenteric stranding and severe ascites was noted (Fig. 1).

Given the patient's history and the radiological findings, a diagnosis of intestinal angioedema was proposed, initiating the specific treatment with $\mathrm{C} 1$ esterase inhibitor. Clinical improvement was seen, with resolution of symptoms within 24 hours.

Symptoms of small bowel angioedema include abdominal pain, nausea and vomiting (1). Physiopathologicaly, what happens is that the small bowel wall becomes thickened and swollen, because of mural edema. These changes can be appreciated in both ultrasound and CT as intestinal wall thickening with low attenuation of the edematous submucosa and preserved serosal and mucosal enhancement $(2,3)$. The findings can be segmental or diffuse and may be associated with intestinal distention as in this case (1, $2)$. Ascites is usually present $(2,3)$.

Radiological appearance is very similar to intestinal vasculitis. Differential diagnoses also include intestinal ischaemia, intramural haemorrhage, nephrotic syndrome and infectious and inflammatory bowel diseases $(1,2)$.

Understanding the condition and correctly identifying it, distinguishing it from others that may need a surgical approach, is important for optimal management, therefore avoiding unnecessary interventions. 


\section{REFERENCES}

1.- Romeu Vilar D. López Rey J. (2015) Angioedema de intestino delgado secundario a inhibidor de la enzima convertidora de la angiotensina Radiología 57, 5, 449-450,

2.- De la Cruz RA, Oliver JM , Bueno A et als ( 2002) Angioedema hereditario: una causa infrecuente de abdomen agudo. Hallazgos en la TC y ecografía abdominal Radiología 44, 3 122-124

3.- Poza Cordón J, de María Pallarés $P$, Caballero Molina T. Ultrasound findings in an abdominal crisis of a patient with hereditary angioedema. Rev Esp Enferm Dig. 2020 May;112(5):418 


\section{ENFERMEDADES DIGESTIVAS}

The Spanish Journal of Gastroenterology

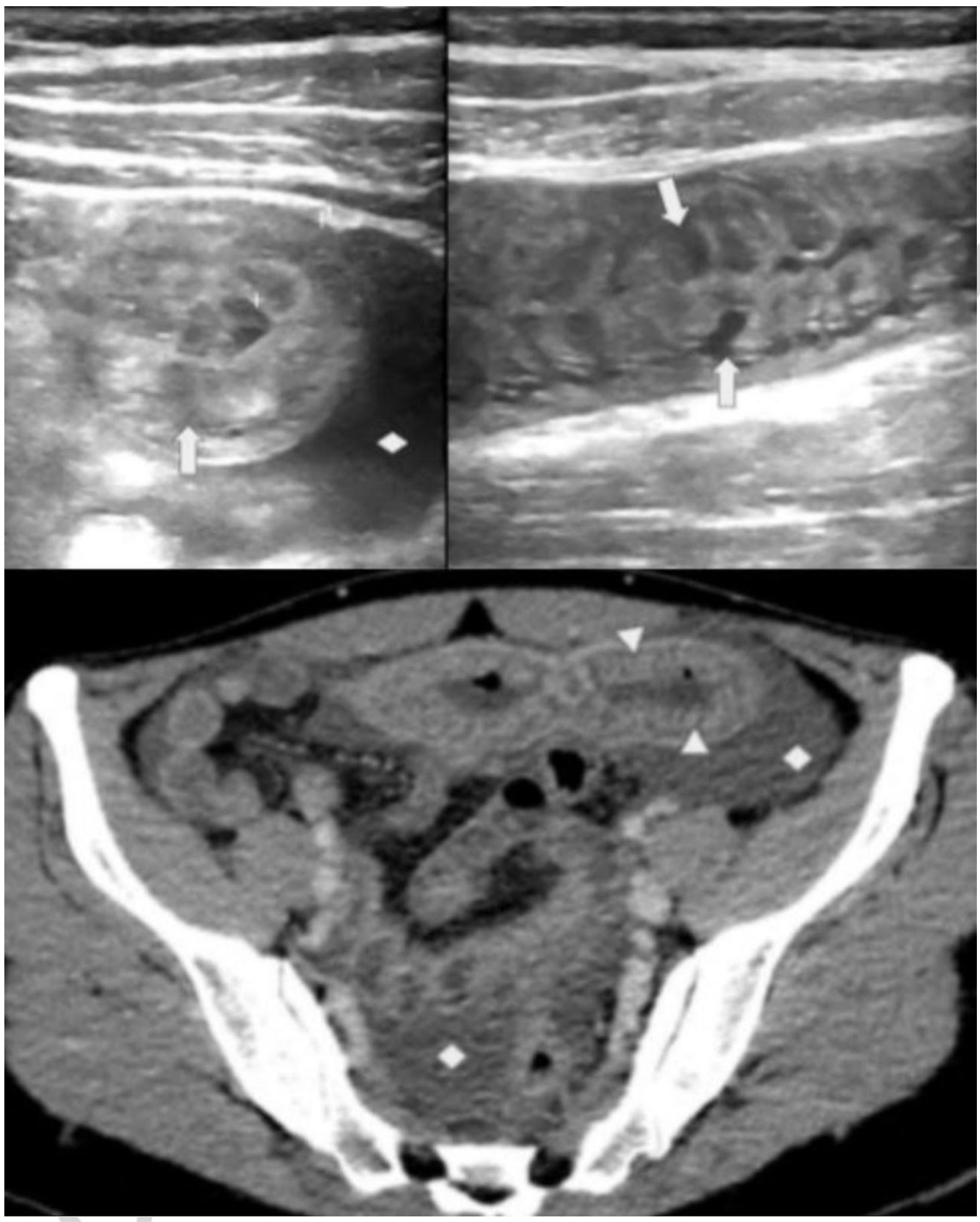

Fig. 1. Ultrasound abdominal examination (image above) at hypogastrium shows a large ileum segment with wall thickening and marked submucosal edema (arrows), preserving its normal layer pattern. 
Contrast enhanced CT scan (image below) shows wall thickened proximal and mid ileum loops with significant submucosal edema and maintained mucosal and subserosal enhancement (arrowheads) as well as moderate ascites (rhombus). 